\title{
Evaluation of the clinical and histological features of paratracheal and hilar gland enlargement
}

\author{
J. R. Mikhail R. A. B. DRURY \\ Central Middlesex Hospital, London, N.W.10 \\ D. N. MitCheLL \\ M.R.C. Tuberculosis and Chest Diseases Unit, The Brompton Hospital, London, S.W.3
}

\begin{abstract}
Summary
Sixty-nine patients with a chest radiograph showing enlargement of the hilar and/or paratracheal lymph nodes were analysed. Ten of these, mainly Asian, were found to be suffering from tuberculosis. Of the remaining fifty-nine, who had sarcoidosis, $12 \%$ were tuberculin-positive. All the cases diagnosed as sarcoidosis had either a positive Kreim test and/or mediastinal lymph node histology compatible with sarcoidosis. $10 \%$ of cases with sarcoidosis showed evidence of uveitis and $10 \%$ showed bone cysts and there was also a high proportion of other extrathoracic lesions.
\end{abstract}

From these studies we conclude that, whilst the currently accepted radiological staging of sarcoidosis serves as a convenient form of reference, these stages do not in any way relate to the clinical stage of disease, or to the histological appearance of affected lymph node tissue.

There is a correlation between a strongly positive Kveim test of three or more granulomas and mediastinal lymph nodes showing confluent granulomata (predominantly of the epithelioid cell-type) with fibrosis. The presence of intra- or peri-granulomatous fibrosis, or even gross diffuse fibrosis, does not seem in itself to be related to the nature of onset, clinical or accepted radiological staging of disease. However the mediastinal lymph nodes in patients with erythema nodosum were predominantly of giant cell-type; these patients were also Kveim-positive. Similar instances of giant cell predominance in the mediastinal lymph nodes were seen in each of the groups examined. Further studies are required to determine whether these cellular characteristics, or other histological features in the mediastinal lymph nodes, might be of prognostic significance.

\section{Objects}

The principal objects of this investigation were:

1. To group patients according to the anatomical location of their enlarged lymph nodes and to correlate this with the results of other investigations in an attempt to determine the aetiology in each group.

2. To determine the occurrence of extra-thoracic lesions as found by full investigation of each system, irrespective of the mode of presentation.

3. To determine from a 'blind' assessment of the histological features of mediastinal lymph node, Kveim test biopsies and radiological features, whether a correlation exists between these findings and the clinical stage of disease.

During the period September 1966 to March 1969 , sixty-nine patients were found to have a chest radiograph showing enlargement of the hilar and/or paratracheal lymph nodes; twenty-two of these showed mottling in one or both lungs.

\section{Methods}

All patients were admitted to hospital and following a full clinical examination the following investigations were carried out:

1. Simple lung function tests.

2. Full haematological examination.

3. Tuberculin test-10 t.u. PPD.

4. Serum proteins and electrophoretic strip.

5. Serum calcium and 24-hr urinary calcium.

6. Alkaline phosphatase.

7. Electrocardiogram.

8. Ocular examination (including slit lamp examination and measurement of lachrymal secretion).

9. Measurement of salivary secretion.

10. X-ray hands and feet for bone cysts.

11. Mediastinoscopy.

12. Kveim test was performed in all cases of suspected sarcoidosis. Where an alternative diagnosis to sarcoidosis appeared evident, no Kveim test was performed.

\section{Results}

The distribution of cases according to the anatomical location is as follows: 
TABLE 1.

\begin{tabular}{lr}
\hline Bilateral hilar and paratracheal nodes & 12 \\
Bilateral hilar nodes & 20 \\
Unilateral hilar nodes & 9 \\
Unilateral hilar and paratracheal nodes & 3 \\
Paratracheal nodes & 3 \\
$\begin{array}{l}\text { Hilar and/or paratracheal nodes with mottling in } \\
\text { one or both lung fields }\end{array}$ & 22 \\
& Total \\
\hline
\end{tabular}

Ten cases showed histological evidence of caseation in the mediastinal lymph node and were distributed among all the above groups. Acid-alcohol fast bacilli were seen on direct smear in two, isolated from culture in two and following animal inoculation in three cases. (These were identified as Mycobacteria tuberculosis.) These ten cases will be referred to later. In a further forty-eight cases, caseation was absent; no mycobacteria were seen or isolated on culture or following animal inoculation. In five cases the histology was equivocal or non-contributory and no mycobacteria were found. In five cases, tissue other than lymph node was removed and in one further case no biopsy was taken; again no mycobacteria were isolated.

Table 2 analyses the results of sputum examination, Kveim and tuberculin tests in all sixty-nine cases. A positive sputum culture was obtained in three cases, two in the group with unilateral hilar nodes and one in the group with hilar node enlargement and pulmonary mottling. These positive sputum cultures were thought to be due to rupture of a tuberculous gland into a bronchus. The Kveim test was performed in fifty-nine cases-forty-eight were positive $(81 \%)$. Seventeen cases had a positive tuberculin test $(25 \%)$. The clinical picture and results of these investigations enabled us to make a diagnosis of tuberculosis in ten $(14.5 \%)$ of the sixty-nine cases (all of these were tuberculin positive). These were treated with tuberculous chemotherapy and their subsequent clinical progress was in keeping with the diagnosis. Nine of these cases came from Asia and one from the Caribbean. Of the remaining fifty-nine cases, twenty-six were male and thirtythree female. Forty-four were in the 20-34 years age group, twelve in the 35-44 years age group and three were over 45 years of age.

Table 3 analyses the incidence of extra-thoracic sarcoid lesions according to the radiological presentation, assessment of onset and the symptoms and signs present on initial examination. Those cases with erythema nodosum were all female and predominantly in the 20-34 years age group. The other cases were classified as 'abrupt' or 'insidious'. Those cases called 'abrupt' had either a recent previous normal chest X-ray or there was a definite onset of symptoms. The other cases were regarded as 'insidious'. The majority of cases in these groups came from Britain, Eire and the Caribbean, but it is of interest that there were three cases of Asian origin and six others, five of whom were coloured.

The incidence of extra-thoracic lesions was of interest: $10 \cdot 2 \%$ had uveitis and a similar percentage had bone cysts. Extra-thoracic lesions, skin lesions (other than erythema nodosum), uveitis and bone cysts were apparent even in hilar lymphadenopathy

TABLE 2. Results of sputum examination, Kveim and tuberculin tests

\begin{tabular}{|c|c|c|c|c|c|c|c|c|c|c|c|c|c|}
\hline \multirow{3}{*}{ Total } & \multirow{3}{*}{$\begin{array}{l}\text { Anatomical location } \\
\text { of radiological shadow }\end{array}$} & \multicolumn{4}{|c|}{ Sputum examination } & \multirow{3}{*}{$\begin{array}{c}\text { Not } \\
\text { known } \\
\text { or not } \\
\text { done }\end{array}$} & \multirow{2}{*}{\multicolumn{3}{|c|}{ Kveim test }} & \multirow{3}{*}{$\begin{array}{c}\text { Not } \\
\text { known } \\
\text { or not } \\
\text { done }\end{array}$} & \multirow{2}{*}{\multicolumn{2}{|c|}{$\begin{array}{l}\text { Tuberculin test } \\
\text { (10 t.u.) PPD }\end{array}$}} & \multirow{3}{*}{$\begin{array}{c}\text { Not } \\
\text { known } \\
\text { or not } \\
\text { done }\end{array}$} \\
\hline & & \multicolumn{2}{|c|}{ Z.N. } & \multicolumn{2}{|c|}{ Culture } & & & & & & & & \\
\hline & & Pos. & Neg. & Pos & $\overline{\text { Neg. }}$ & & Pos. & Equiv. & Neg. & & Pos. & Neg. & \\
\hline 12 & $\begin{array}{l}\text { Bilateral hilar and } \\
\text { paratracheal nodes }\end{array}$ & 0 & 8 & 0 & 8 & 4 & 10 & 0 & 0 & 2 & 2 & 10 & 0 \\
\hline 20 & Bilateral hilar nodes & 0 & 18 & 0 & 18 & 2 & 15 & 0 & 2 & 3 & 4 & 15 & 1 \\
\hline 9 & Unilateral hilar nodes & 0 & 9 & 2 & 7 & 0 & 5 & 0 & 2 & 2 & 3 & 6 & 0 \\
\hline 3 & $\begin{array}{l}\text { Unilateral hilar and } \\
\text { paratracheal nodes }\end{array}$ & 0 & 2 & 0 & 2 & 1 & 2 & 0 & 0 & 1 & 1 & 2 & 0 \\
\hline 3 & Paratracheal nodes & 0 & 3 & 0 & 3 & 0 & 1 & 0 & 0 & 2 & 3 & 0 & 0 \\
\hline 22 & $\begin{array}{l}\text { Hilar and/or para- } \\
\text { tracheal nodes with } \\
\text { mottling in one or } \\
\text { both lungs }\end{array}$ & 0 & 19 & 1 & 18 & 3 & 15 & 1 & 6 & 0 & 4 & 18 & 0 \\
\hline 69 & & 0 & 59 & 3 & 56 & 10 & 48 & 1 & 10 & 10 & 17 & 51 & 1 \\
\hline
\end{tabular}


TABLE 3. Incidence of extrathoracic sarcoid lesions

\begin{tabular}{|c|c|c|c|c|c|c|c|}
\hline \multirow{2}{*}{$\begin{array}{c}\text { Total } \\
\text { patients }\end{array}$} & \multirow{2}{*}{$\begin{array}{l}\text { Radiological } \\
\text { presentation }\end{array}$} & \multirow{2}{*}{$\begin{array}{l}\text { Assessment } \\
\text { of onset }\end{array}$} & \multirow{2}{*}{$\begin{array}{l}\text { Symptoms and signs } \\
\text { on presentation }\end{array}$} & \multirow{2}{*}{ No. } & \multicolumn{3}{|c|}{$\begin{array}{c}\text { Extrathoracic sarcoid } \\
\text { lesions }\end{array}$} \\
\hline & & & & & Uveitis & Bone cysts & Other \\
\hline 6 & $\begin{array}{l}\text { Hilar lymphadenopathy } \\
\text { only }\end{array}$ & Abrupt & $\begin{array}{l}\text { Erythema nodosum } \\
\text { Arthralgia }\end{array}$ & $\begin{array}{l}6 \\
2\end{array}$ & 0 & 0 & 0 \\
\hline 19 & $\begin{array}{l}\text { Hilar lymphadenopathy } \\
\text { only }\end{array}$ & Abrupt & $\begin{array}{l}\text { Pulmonary } \\
\text { Skin lesions } \\
\text { (other than EN) } \\
\text { Ocular } \\
\text { Febrile }\end{array}$ & $\begin{array}{r}13 \\
1 \\
1 \\
1\end{array}$ & 1 & 2 & $\begin{array}{l}\text { Palpable lymph nodes (2) } \\
\text { CNS (1) }\end{array}$ \\
\hline 13 & $\begin{array}{l}\text { Hilar lymphadenopathy } \\
\text { only }\end{array}$ & Insidious & $\begin{array}{l}\text { Asymptomatic } \\
\text { Pulmonary }\end{array}$ & $\begin{array}{r}12 \\
1\end{array}$ & 1 & 1 & \\
\hline 12 & $\begin{array}{l}\text { Hilar lymphadenopathy } \\
\text { with pulmonary mottling }\end{array}$ & Abrupt & $\begin{array}{l}\text { Pulmonary } \\
\text { Skin lesions } \\
\text { (other than EN) } \\
\text { Erythema nodosum } \\
\text { Ocular }\end{array}$ & $\begin{array}{l}8 \\
3 \\
1 \\
2\end{array}$ & 2 & $\begin{array}{l}\text { H } \\
\text { L } \\
\text { S }\end{array}$ & $\begin{array}{l}\text { Hepatic* (1) } \\
\text { Lachryn.al gland (2) } \\
\text { Skin lesions (3) }\end{array}$ \\
\hline 9 & $\begin{array}{l}\text { Hilar lymphadenopathy } \\
\text { with pulmonary mottling }\end{array}$ & Insidious & Ocular & 1 & 2 & 1 & $\begin{array}{l}\text { Lachrymal and paratid } \\
\text { Enlargement (1) }\end{array}$ \\
\hline 59 & & & & & $\begin{array}{c}6 \\
(10 \cdot 2 \%)\end{array}$ & $\begin{array}{c}6 \\
(10 \cdot 2 \%)\end{array}$ & \\
\hline
\end{tabular}

* Later developed skin lesions.

TABLE 4. Histological features of positive Kveim tests

\begin{tabular}{|c|c|c|c|c|c|c|}
\hline \multirow[b]{2}{*}{ Total Positive } & \multirow[b]{2}{*}{$\begin{array}{l}\text { Radiological presentation and } \\
\text { nature of onset }\end{array}$} & \multicolumn{5}{|c|}{ Kveim test } \\
\hline & & $\begin{array}{c}1-3 \\
\text { Granulomas }\end{array}$ & $\begin{array}{l}\text { More than } \\
\text { three granulomas }\end{array}$ & Confluent & $\begin{array}{l}\text { Semi- } \\
\text { confluent }\end{array}$ & Fibrinoid \\
\hline 6 & $\begin{array}{l}\text { Hilar lymphadenopathy only } \\
\text { (abrupt-all EN) }\end{array}$ & 0 & 6 & 5 & 1 & 2 \\
\hline 17 & $\begin{array}{l}\text { Hilar lymphadenopathy only } \\
\text { (abrupt) }\end{array}$ & $\begin{array}{l}1 \\
\text { (Med. node: } \\
\text { gross diffuse } \\
\text { fibrosis) }\end{array}$ & 16 & 14 & 2 & 4 \\
\hline 11 & $\begin{array}{l}\text { Hilar lymphadenopathy only } \\
\text { (insidious) }\end{array}$ & 1 & 10 & 7 & 4 & 4 \\
\hline 7 & $\begin{array}{l}\text { Hilar lymphadenopathy with } \\
\text { pulmonary mottling (abrupt) }\end{array}$ & 1 & 6 & 4 & 3 & 1 \\
\hline 7 & $\begin{array}{l}\text { Hilar lymphadenopathy with } \\
\text { pulmonary mottling (insidious) }\end{array}$ & 1 & 6 & 6 & 1 & 4 \\
\hline 48 & & 4 & 44 & 36 & 11 & 15 \\
\hline
\end{tabular}

of abrupt onset. Skin lesions were present in three cases of hilar lymphadenopathy with mottling. Lachrymal and parotid gland enlargement also occurred in three cases in the same group. Sarcoidosis was confirmed in all fifty-nine cases, either by mediastinoscopy, Kveim test or both. $86 \%$ were mediastinoscopy positive and $81 \%$ Kveim positive. In hilar lymphadenopathy with erythema nodosum all were Kveim positive and in those cases in which a gland was obtained the histology was similarly positive. It is, however, realised that in this group a diagnosis can usually be made on clinical grounds without resorting to biopsy procedures. In those cases with hilar lymphadenopathy only, Kveim test and mediastinoscopy produced similarly high numbers of positive results and no significant statistical difference was noted. Therefore, the Kveim test appears to be the procedure of choice in the first instance. In the hilar lymphadenopathy and mottling group, there is an advantage to mediastinoscopy at 
TABLE 5. Histological features of positive mediastinal lymph nodes

\begin{tabular}{|c|c|c|c|c|c|c|c|c|}
\hline \multirow[b]{3}{*}{$\begin{array}{l}\text { Total } \\
\text { Positive }\end{array}$} & \multirow[b]{3}{*}{$\begin{array}{l}\text { Radiological presentation } \\
\text { and nature of onset }\end{array}$} & \multicolumn{7}{|c|}{ Mediastinal lymph node } \\
\hline & & \multicolumn{4}{|c|}{ Granulomas } & \multicolumn{3}{|c|}{ Fibrosis } \\
\hline & & $\begin{array}{l}\text { Epithelioid } \\
\text { cell }\end{array}$ & $\begin{array}{l}\text { Giant } \\
\text { cell }\end{array}$ & Confluent & $\begin{array}{l}\text { Semi- } \\
\text { confluent }\end{array}$ & $\begin{array}{l}\text { Intragranu- } \\
\text { lomatous }\end{array}$ & $\begin{array}{l}\text { Perigranu- } \\
\text { lomatous }\end{array}$ & $\begin{array}{c}\text { Gross diffuse } \\
\text { fibrosis }\end{array}$ \\
\hline 5 & $\begin{array}{l}\text { Hilar lymphadenopathy } \\
\text { only (abrupt—all EN) }\end{array}$ & 1 & 4 & 3 & 2 & 3 & 0 & 0 \\
\hline 13 & $\begin{array}{l}\text { Hilar lymphadenopathy } \\
\text { only (abrupt) }\end{array}$ & 10 & 2 & 8 & 4 & 9 & 4 & 1 \\
\hline 13 & $\begin{array}{l}\text { Hilar lymphadenopathy } \\
\text { only (insidious) }\end{array}$ & 10 & 2 & 6 & 6 & 6 & 3 & 1 \\
\hline 11 & $\begin{array}{l}\text { Hilar lymphadenopathy } \\
\text { with pulmonary } \\
\text { mottling (abrupt) }\end{array}$ & 8 & 3 & 5 & 6 & 8 & 5 & 0 \\
\hline 9 & $\begin{array}{l}\text { Hilar lymphadenopathy } \\
\text { with pulmonary } \\
\text { mottling (insidious) }\end{array}$ & 8 & 1 & 6 & 3 & 7 & 4 & 0 \\
\hline 51 & & 37 & 12 & 28 & 20 & 34 & 16 & 2 \\
\hline
\end{tabular}

the $5 \%$ level. As will be seen in Table 4, all the cases with bilateral hilar lymphadenopathy and erythema nodosum had strongly positive Kveim tests, mainly with confluent granulomata. It is noteworthy that one case of abrupt onset of hilar lymphadenopathy, whose mediastinal lymph-node biopsy showed gross diffuse fibrosis, also showed a weakly positive Kveim test with less than three granulomas. In the hilar lymphadenopathy group, Kveim tests were mainly strongly positive with confluent granulomas; whereas in those cases with mottling, the lesions, although mainly strongly positive, showed a greater proportion of semi-confluent lesions. The presence of fibrinoid necrosis was not a characteristic of any particular radiological or ethnic group.
Table 5 shows the histological features of the mediastinal lymph nodes. As previously stated, gross diffuse fibrosis was present in two patients with hilar lymphadenopathy. The presence of intra- or peri-granulomatous fibrosis does not seem to be related to the nature of onset, or the clinical or presently accepted radiological staging of disease. In cases with erythema nodosum, four out of five cases showed predominantly giant cell lesions, and predominantly giant cell lesions were also seen in each of the remaining groups; it may be that this could have some prognostic significance. A predominance of confluent or semi-confluent granulomas was not associated with any particular group nor clinical picture. 